\title{
SOME GEOMETRIC PROPERTIES OF DIFFERENCE SEQUENCE SPACES OF ORDER $m$ DERIVED BY GENERALIZED MEANS AND COMPACT OPERATORS
}

\author{
Amit Maji AND P. D. SRIVAstava
}

\begin{abstract}
We have introduced a new sequence space $l\left(r, s, t, p ; \Delta^{(m)}\right)$ combining by using generalized means and difference operator of order $m$. Some topological properties as well as geometric properties namely Banach-Saks property of type $p$ and uniform Opial property have been studied. Furthermore, the $\alpha-, \beta-, \gamma$-duals of this space are computed and also obtained necessary and sufficient conditions for some matrix transformations from $l\left(r, s, t, p ; \Delta^{(m)}\right)$ to $l_{\infty}, l_{1}$. Finally, we obtained some identities or estimates for operator norms and measure of noncompactness of some matrix operators on the BK space $l_{p}\left(r, s, t ; \Delta^{(m)}\right)$ by applying the Hausdorff measure of noncompactness.
\end{abstract}

Mathematics subject classification (2010): 46A45, 46B15, 46B50.

Keywords and phrases: Difference operator, generalized means, matrix transformation, Hausdorff measure of noncompactness, compact operators.

\section{REFERENCES}

[1] B. Altay, F. BAŞAR, On the paranormed Riesz sequence spaces of non-absolute type, Southeast Asian Bull. Math., 26, 5 (2003), 701-715.

[2] B. Altay, F. BAŞAR, The fine spectrum and the matrix domain of the difference operator $\Delta$ on the sequence space $l_{p},(0<p<1)$, Commun. Math. Anal. 2, 2 (2007), 1-11.

[3] C. Aydin, F. BAŞAR, Some new difference sequence spaces, Appl. Math. Comput. 157, 3 (2004), 677-693.

[4] F. BAŞAR, B. Altay, Matrix mappings on the space $b s(p)$ and its $\alpha-\beta-, \gamma$-duals, Aligarh Bull. Math. 21, 1 (2002), 79-91.

[5] F. BAŞAR, B. ALTAY, On the space of sequences of p-bounded variation and related matrix mappings, Ukrainian Math. J. 55, 1 (2003), 136-147.

[6] F. Başar, B. Altay, M. Mursaleen, Some generalizations of the space bv of p-bounded variation sequences, Nonlinear Anal. 68, 2 (2008), 273-287.

[7] M. BAŞARIR AND E. E. KARA, On some difference sequence spaces of weighted means and compact operators, Ann. Funct. Anal, 2, 2 (2011), 114-129.

[8] M. BAŞARIR, E. E. KARA, On the mth order difference sequence space of generalized weighted mean and compact operators, Acta Math. Sci. Ser. B Engl. Ed. 33, 3 (2013), 797-813.

[9] M. BAŞARIR, E. E. KARA, S. KONCA, On some new weighted Euler sequence spaces and compact operators, Math. Inequal. Appl. 17, 2 (2014), 649-664.

[10] R. ÇOLAK, M. ET, On some generalized difference sequence spaces and related matrix transformations, Hokkaido Math. J., 26, 3 (1997), 483-492.

[11] Y. A. CUI AND H. HUDZIK, Some geometric properties related to fixed point theory in Cesàro spaces, Collect. Math., 50, 3 (1999), 277-288.

[12] Y. A. CUI AND H. HUDZIK, On the Banach-Saks and weak Banach-Saks properties of some Banach sequence spaces, Acta Sci. Math. (Szeged), 65, 1-2 (1999), 179-187.

[13] Y. A. Cui AND C. Meng, Banach-Saks property and property ( $\beta$ ) in Cesàro sequence spaces, Southeast Asian Bull. Math., 24 (2000), 201-210. 
[14] S. Delpech, A short proof of Pitt's compactness theorem, Proc. Amer. Math. Soc., 137, 4 (2009), 1371-1372.

[15] I. Djolović, E. Malkowsky, Matrix transformations and compact operators on some new mthorder difference sequence spaces, Appl.Math.Comput. 198, 2 (2008), 700-714.

[16] I. Djolović, E. Malkowsky, A note on compact operators on matrix domains, J. Math. Anal. Appl. 340, 1 (2008), 291-303.

[17] I. Djolović, On the space of bounded Euler difference sequences and some classes of compact operators, Appl. Math. Comput. 182, 2 (2006), 1803-1811.

[18] M. ET, M. KaraKaş, V. KARA KAYA, Some geometric properties of a new difference sequence space defined by de la Vallée-Poussin mean, Appl. Math. Comput. 234 (2014), 237-244.

[19] K.-G. Grosse-ERdmann, Matrix transformations between the sequence spaces of Maddox, J. Math. Anal. Appl. 180, 1 (1993), 223-238.

[20] A. M. JARRAH, E. MALKOWSKY, Ordinary, absolute and strong summability and matrix transformations, Filomat 17 (2003), 59-78.

[21] H. Hudzik, V. Karakaya, M. Mursaleen, Mohammad, N. Şimşek, Banach-Saks type and Gurarii modulus of convexity of some Banach sequence spaces, Abstr. Appl. Anal. 2014, Art. ID 427382, 9 pp.

[22] H. Kizmaz, On certain sequence spaces, Canad. Math. Bull. 24, 2 (1981), 169-176.

[23] I. J. MAdDOX, Paranormed sequence spaces generated by infinite matrices, Proc. Cambridge Philos. Soc. 64 (1968) 335-340.

[24] A. Maji, A. Manna, P. D. SRivastava, Some mth-order diference sequence spaces of generalized means and compact operators, Ann. Funct. Anal., 6, 1 (2015), 170-192.

[25] E. Malkowsky, V. RAkočEvić, An introduction into the theory of sequence spaces and measure of noncompactness, Zb. Rad. (Beogr.), 9 (17) (2000), 143-234.

[26] E. Malkowsky, V. RakočEvić, On matrix domains of triangles, Appl. Math. Comput. 189 (2007), $1146-1163$.

[27] E. Malkowsky, E. SAvaş, Matrix transformations between sequence spaces of generalized weighted means, Appl. Math. Comput., 147 (2004), 333-345.

[28] A. Manna, A. Maji, P. D. SRivastaVa, Difference sequence spaces derived by using generalized means, J. Egyptian Math. Soc, 23, 1 (2015), 127-133.

[29] M. Murs aleEn, A. K. Noman, Applications of the Hausdorff measure of noncompactness in some sequence spaces of weighted means, Comput. Math. Appl., 60, 5 (2010), 1245-1258.

[30] M. Murs AleEn, A. K. Noman, On generalized means and some related sequence spaces, Comput. Math. Appl. 61, 4 (2011), 988-999.

[31] P. N. NG, P. Y. LeE, Cesàro sequences spaces of non-absolute type, Comment. Math. Prace Mat., 20, 2 (1978), 429-433.

[32] N. Petrot, S. SuAntai, Uniform Opial properties in generalized Cesàro sequence spaces, Nonlinear Anal. 63, 8 (2005), 1116-1125.

[33] H. Polat, F. BAŞAR, Some Euler spaces of difference sequences of order $m$, Acta Math. Sci. Ser. B Engl. Ed., 27B, 2 (2007), 254-266.

[34] H. Polat, V. Karakaya, N. ŞımŞEK, Difference sequence spaces derived by using a generalized weighted mean, Appl. Math. Lett. 24, 3 (2011), 608-614.

[35] S. PRus, Banach spaces with uniform Opial property, Nonliner Anal. Theory Appl. 18, 8 (1992), 697-704.

[36] N. ŞIMŞEK, V. KARAKAYA, Structure and some geometric properties of generalized Cesàro sequence space, Int. J. Contemp. Math. Sci. 3, 5-8 (2008), 389-399.

[37] A. Wilansky, Summability through Functional Analysis, North-Holland Math. Stud., 85, Elsevier Science Publishers, Amsterdam, New York, Oxford, 1984. 